\title{
BRANDING “KERIPIK SINGKONG” UNTUK MEWUJUDKAN DESA SEJAHTERA MANDIRI BERBASIS EKONOMI KREATIF
}

\author{
Ika Anggraheni1, Ela Yuniar1, Mohamad Saleh Tuanany², Hadiyatus Tsaniyah1, \\ Muhammad Yusuf Ahsani' ${ }^{1}$, Karina Safitri Rachmawati ${ }^{3}$, Muhammad Ibnul Qayyim², \\ Antoni Bagus Pradana3 ${ }^{3}$ Anggi Ayu Dwi Narwani' ${ }^{1}$ Achmad Rafly Firdauzie ${ }^{3}$, Rizma \\ Noer Hidayati ${ }^{3}$, Riska Dwi Pratiwi ${ }^{1}$, Laela Octaviana Yusuf ${ }^{4}$ \\ ${ }^{1}$ Fakultas Agama Islam, Universitas Islam Malang \\ ${ }^{2}$ Fakultas Teknik, Universitas Islam Malang \\ ${ }^{3}$ Fakultas Keguruan dan Ilmu Pendidikan, Universitas Islam Malang \\ ${ }^{4}$ Fakultas Ilmu Administrasi, Universitas Islam Malang \\ Korespondensi email: ika.anggraheni@unisma.ac.id
}

\begin{abstract}
ABSTRAK
Banyaknya potensi yang dimiliki oleh Desa Dadapan menjadikan semakin meningkat peluang perekonomian yang dimilikinya dan menjadikan deesa mandiri sejahtera berbasis ekonomi kreatif. Salah satunya dengan membuat industri kecil dalam rumah tangga untuk mengolah hasil pertanian yang dimilikinya dan memberikan kemasan yang menarik sehingga menarik perhatian konsumen dan berhasil memasarkan produk dengan lebih baik. Dengan jumlah penghasilan yang lebih baik setiap waktunya, menjadikan kami mahasiswa dari Kelompok 2 KKN-PPM Tematik Desa Dadapan ingin mengembangkan produk olahan tersebut menjadi produk yang digemari oleh seluruh penjuru dan tidak hanya di wilayah Desa Dadapan saja. Dengan memberikan dorongan kepada pemilik usaha untuk mengembangkan brand dan kemasan sehingga menjadi lebih menarik perhatian konsumen. Untuk mencapai tujuan yang diharapkan, penulis menggunakan metode penggalian informasi dan metode analisis data deskriptif dengan observasi dan wawancara. Dengan menggunakan brand dan kemasan baru menghasilkan produk keripik singkong Bu Rinda semakin banyak dikenal dan lebih memiliki banyak konsumen. Sehingga dapat meningkatkan penghasilan ekonomi Bu Rinda dan semakin banyak tenaga usaha yang dibutuhkan karena semakin banyaknya produk yang diproduksi. Harapannya branding dapat dijalankan secara berkelanjutan. Sehingga Desa Dadapan dapat menjadi Desa Sejahtera dan mandiri Berbasis Ekonomi Kreatif Melalui Pemanfaatan Ubi Singkong.
\end{abstract}

Kata Kunci: branding; keripik singkong; ekonomi kreatif.

\section{PENDAHULUAN}

Desa Dadapan merupakan salah satu desa yang berada di Kecamatan Wajak Kabupaten Malang. Desa Dadapan ini berada di daerah pegunungan dan memiliki beragam potensi seperti dalam bidang pertanian, peternakan, dan perdagangan. Banyaknya potensi yang dimiliki oleh Desa Dadapan menjadikan semakin meningkat peluang perekonomian yang dimilikinya dan menjadikan desa mandiri sejahtera berbasis ekonomi kreatif (Hatneny, Mahardani, \& Saraswati, 2019; Satria, 2009). Salah satunya dengan membuat industri kecil dalam rumah tangga untuk mengolah hasil pertanian yang dimilikinya dan memberikan 
kemasan yang menarik sehingga menarik perhatian konsumen dan berhasil memasarkan produk dengan lebih baik (Sholihah, Normaladewi, \& Laksono, 2019).

Industri kecil dan rumah tangga memiliki tiga alasan penting yang mendasari keberadaannya di Indonesia. Pertama, adalah karena kinerja industri kecil dan rumah tangga cenderung lebih baik dalam menghasilkan tenaga kerja yang produktif. Kedua, sebagai bagian dari dinamikanya, industri kecil dan rumah tangga yang sering mencapai peningkatan produktivitasnya melalui investasi dan perubahan teknologi. Ketiga, karena sering diyakini bahwa industri kecil dan rumah tangga memiliki keunggulan dalam hal fleksibilitas ketimbang usaha besar (Joesyiana, 2017; Anam, Arifin, Widiastuti, \& Arifin, 2020).

Menurut Fatria, Jahrizal, \& Pailis (2017) Industri adalah sejumlah perusahaan yang memproduksi dan menjual sejumlah produk yang serupa, memanfaatkan teknologi yang serupa dan mungkin juga mengakses faktor produksi (input) dari pasar faktor produksi yang sama. Industri rumah tangga di Kabupaten Malang tepatnya di desa Dadapan, Wajak sangat berpotensi untuk dikembangkan, karena tidak hanya berperan dalam penyediaan lapangan pekerjaan, namun juga berperan dalam pemberdayaan ekonomi masyarakat. Usaha keripik singkong merupakan Industri Pengolahan Singkong di Kabupaten Malang yang tergolong dalam industri rumah tangga, dan bergerak di bidang usaha pengolahan keripik singkong. Diketahui bahwa usaha keripik singkong Industri Pengolahan keripik singkong di Kabupaten Malang mengalami suatu perkembangan pada tahun 2016 sampai dengan tahun 2020 . Dengan jumlah penghasilan yang lebih baik setiap waktunya, menjadikan kami mahasiswa dari Kelompok 2 KKN-PPM Tematik Desa Dadapan ingin mengembangkan produk olahan tersebut menjadi produk yang digemari oleh seluruh penjuru dan tidak hanya di wilayah Desa Dadapan saja. Dengan memberikan dorongan kepada pemilik usaha untuk mengembangkan brand dan kemasan sehingga menjadi lebih menarik perhatian konsumen, yang dengan hal tersebut menjadikan usaha yang dimiliki oleh $\mathrm{Bu}$ Rinda menjadi lebih berkembang, dan dapat membuka lapangan pekerjaan di Desa Dadapan. Dengan begitu menjadikan Desa Dadapan menjadi lebih berkembang dari sebelumnya.

\section{METODE}

Untuk mencapai tujuan yang diharapkan, penulis menggunakan metode penggalian informasi dan metode analisis data deskriptif. Observasi merupakan tahap awal untuk pencarian data tentang keadaan desa Dadapan kecamatan Wajak Kabupaten Malang. Dalam observasi ini bersifat langsung tidak berdasarkan teori, pikiran dan pendapat. Namun, menemukan langsung sesuai target. Observasi ini juga bersida orisinil yang hasil dari pengamatan merupakan hasil serapan indra bukan dilaporkan dari orang lain (Fathani, 2020). Dapat dikatakan bahwa seluruh hasil pengamatan adalah sesuai dengan dakta yang berada di desa Dadapan.

Metode wawancara juga dilakukan oleh penulis dengan tujuan merekontruksi kejadian yang baru atau telah lampau untuk mendapatkan data yang dibutuhkan. Yang menjadi sasaran dalam wawancara yaitu kepala desa Dadapan dan Masyarakat desa Dadapan.

\section{HASIL DAN PEMBAHASAN}

Penulis telah memperoleh beberapa temuan dan informasi tentang pengolahan produk olahan rumah tangga di Desa Dadapan. Diantaranya informasi yang kami peroleh dari kepala desa bahwasannya hasil terdapat olahan produk pertanian di masyarakat Desa Dadapan. namun sayangnya warga belum dapat meningkatkan pemasaran/penjualan produk tersebut. Oleh karena itu dengan adanya KKN di Desa Dadapan ini diharapkan dapat 
membantu dalam proses pengemasan dan pemasaran agar produk yang telah diolah memiliki harga jual dan pemasaran yang lebih tinggi.

Setelah kami survei tentang masyarakat yang mengolah produk pertanian, ternyata di Desa Dadapan hanya terdapat satu tempat pengolahan tersebut. Produk yang diolah yaitu singkong yang dijadikannya sebagai keripik yang telah ada sejak 2016. Pemilik usaha tersebut biasa disebut dengan Bu Rinda, beliau mengolah singkong menjadi keripik singkong dengan bumbu khas yang dimilikinya. Karena beliau merupakan keturunan sumatera, jadi keripik tersebut ada khas sumateranya sehingga berbeda dengan keripik singkong lainnya.

Sebelumnya keripik singkong Bu Rinda hanya ada dalam kemasan plastik biasa dan tidak ada labelnya. Kemuadian setelah kedatangan mahasiswa KKN-PPM Tematik Unisma Kelompok 2, yang dengan kedatangan mereka membawa inovasi baru yaitu dengan memberikan brand dan kemasan yang menarik. Mahasiswa KKN membuat logo, sticker, dan plastik yang lebih bagus. Setelah itu membantu pemasaran lewat media sosial seperti Instagram dan WhatsApp sehingga keripik singkong Bu Rinda mulai dikenal banyak orang dan memiliki banyak peminat hingga saat ini. Dengan semakin banyak oeminat keripik singkong Bu Rinda, maka semakin berkembang pula pendapatan ekonomi yang didapat oelh Bu Rinda.

Dengan semakin berkembangnya peminat keripik singkong Bu Rinda, maka semakin banyak pula tenaga yang dibutuhkan Bu Rinda untuk menyelesaikan pesanan-pesanan yang didapatkannya. Dengan begitu, Bu Rinda dapat membuka lapangan kerja bagi masyarakat desa Dadapan yang kemudian akan menambah penghasilan ekonomi untuk masyarakat desa Dadapan. Kemudian dari hal tersebut kami dapat membahas dan menyusun Program Kerja guna mewujudkan desa sejahtera mandiri berbasis ekonomi kreatif melalui pemanfaatan ubi singkong. Salah satunya adalah dengan meningkatkan pemasaran produk yang dibuat oleh $\mathrm{Bu}$ Rinda.

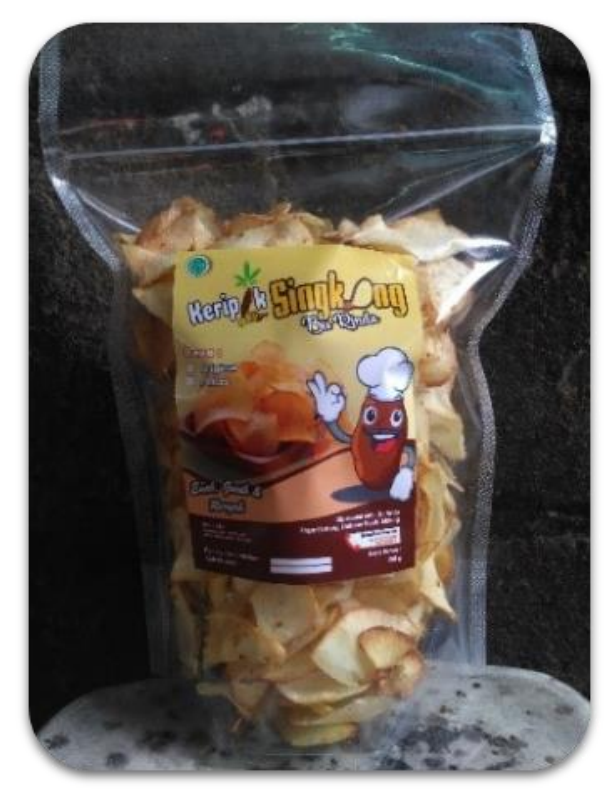

Gambar 1. Keripik Singkong Bu Rinda Desa Dadapan Sumber: Dokumentasi pribadi

\section{KESIMPULAN}

Dari pembahasan dapat disimpulkan bahwa keripik singkong Bu Rinda yang awalnya hanya dikenal di Desa Dadapan, saat ini telah dikenal banyak orang di luar Desa Dadapan. Yang awalnya tidak memiliki brand, dengan kedatangan mahasiswa KKN akhirnya keripik 
singkong Bu Rinda telah memiliki brand dan kemasan yang menarik. Sehingga memperoleh pemasaran yang lebih baik dari sebelumnya.

Harga dari keripik singkong Bu Rinda ada 2 (dua) macam. Ukuran besar (sekitar 250 gram) dengan harga 15.000-20.000. Dan ukuran mini (sekitar 80 gram) dengan harga 5.000. keripik singkong Bu Rinda bertahan satu bulan dari pengemasan. Harapannya branding dari keripik singkong Bu Rinda dapat dijalankan secara berkelanjutan. Sehingga Desa Dadapan dapat menjadi Desa Sejahtera dan mandiri Berbasis Ekonomi Kreatif Melalui Pemanfaatan Ubi Singkong.

\section{DAFTAR RUJUKAN}

Anam, A. K., Arifin, M., Widiastuti, A., \& Arifin, Z. (2020). Peningkatan daya saing ukm rotan indah jepara menuju pasar sasaran ekspor. Jurnal Inovasi Hasil Pengabdian Masyarakat (JIPEMAS), 3(1), 33-45. https://doi.org/10.33474/jipemas.v3i1.4777

Fathani, A. H. (2020). PEMBERDAYAAN MASYARAKAT UNTUK MEWUJUDKAN DESA MANDIRI DAN SEJAHTERA BERBASIS ENTREPRENEUR MELALUI PEMANFAATAN BUAH SALAK Abdul Halim Fathani, 1(1), 55-58.

Fatria, M. A., Jahrizal, \& Pailis, E. A. (2017). STRATEGI PENGEMBANGAN INDUSTRI RUMAH TANGGA DI KOTA PEKANBARU (Studi Kasus Usaha Jamur Crispy Industri Pengolahan Jamur Tiram). Jurnal Online Mahasiswa Bidang Ilmu Ekonomi, 4(1), 9-15. Retrieved from https://jom.unri.ac.id/index.php/JOMFEKON/article/view/12291

Hatneny, A. I., Mahardani, A. S., \& Saraswati, E. (2019). Pemberdayaan Masyarakat Pada UKM Depo Air Minum Tirta Barokah Dan Bakso Tuna Cintaku. Jurnal Inovasi Hasil Pengabdian Masyarakat (JIPEMAS), 2(1), 54-62. https://doi.org/10.33474/jipemas.v2i1.1604

Joesyiana, K. (2017). Strategi Pengembangan Industri Rumah Tangga di Kota Pekanbaru (Studi Kasus Usaha Tas Rajut Industri Pengolahan Kreatifitas Tali Kur). Jurnal Valuta, $\begin{array}{lcr}3(1), & 159-172 . & \text { Retrieved }\end{array}$ https://journal.uir.ac.id/index.php/valuta/article/view/1275

Satria, D. (2009). Strategi Pengembangan Ekowisata Berbasis Ekonomi Lokal Dalam Rangka Program Pengentasan Kemiskinan di Wilayah Kabupaten Malang. Journal of Indonesian Applied Economics, 3(1), 37-47. https://doi.org/10.21776/ub.jiae.2009.003.01.5

Sholihah, F. A., Normaladewi, A., \& Laksono, P. T. (2019). Pengolahan Plastik Bekas Menjadi Bantal Hias Di Desa Ngempit Kecamatan Kraton Kabupaten Pasuruan. Jurnal Inovasi Hasil Pengabdian Masyarakat (JIPEMAS), 2(1), 9-17. https://doi.org/10.33474/jipemas.v2i1.1640 